\title{
OPTIMIZING THE DIFFERENTIAL PULSE ANODIC STRIPPING VOLTAMMETRY METHOD WITH A HANGING MERCURY ELECTRODE FOR THALLIUM (I) DETERMINATION IN THE PRESENCE OF LEAD (II) AND COPPER (II) FOR APPLICATION IN CONTAMINATED SOILS
}

(Optimizacion del método voltamperómetrico de redisolución anódica de pulso diferencial con un electrodo colgante de mercurio para la determinación de talio [I] en presencia de plomo [II] y de cobre [II] para su aplicación en suelos contaminados)

\author{
Yusniel CRUZ-HERNÁNDEZ ${ }^{1}$, Mario VILLALOBOS ${ }^{1 *}$, \\ José Luz GONZÁLEZ-CHAVEZ ${ }^{2}$ and Nadia MARTÍNEZ-VILLEGAS ${ }^{3}$
}

\footnotetext{
${ }^{1}$ Laboratorio de Geoquímica Ambiental, Laboratorio Nacional de Geoquímica y Mineralogía (LANGEM), Instituto de Geología, Universidad Nacional Autómoma de México, Ciudad Universitaria, 04510 Ciudad de México, México.

${ }^{2}$ Departamento de Química Analítica, Facultad de Química, Universidad Nacional Autónoma de México, Ciudad Universitaria, 04510 Ciudad de México, México

${ }^{3}$ Instituto Potosino de Investigación Científica y Tecnológica, División de Geociencias, 78216 San Luis Potosí, México

*Corresponding author: mariov@geologia.unam.mx
}

(Received November 2017; accepted June 2018)

Key words: voltamperometric, interference, trace analysis, thallium, EDTA, soil samples

\begin{abstract}
The conditions that allow thallium (I) determination in the presence of lead (II) and copper (II) were optimized without prior separation of these cations, using a previously developed differential pulse anodic stripping voltammetry (DPASV) method, with a hanging mercury drop working electrode (HMDE) and a $\mathrm{Ag} / \mathrm{AgCl}$ reference electrode. Unfortunately, the electrochemical activity of lead (II) interferes with this determination, but the addition of $0.1 \mathrm{M}$ EDTA complexing agent $(\mathrm{at} \mathrm{pH}=4.6)$ causes a shift in the $\mathrm{Pb}$ (II) peak to more negative values, making it possible to quantify $\mathrm{Tl}(\mathrm{I})$ in its presence at an optimal deposition potential of $-0.550 \mathrm{~V}$. However, the $\mathrm{Cu}(\mathrm{II})$ reduction peak, which is normally found far away from that of $\mathrm{Tl}(\mathrm{I})$, is also shifted when complexed with EDTA, approaching the Tl(I) peak and becoming an interfering ion. The deposition time and scan rate that were found optimal for the determination were $30 \mathrm{~s}$ and $10 \mathrm{mV} / \mathrm{s}$, respectively. Under these conditions it was found that maximum concentration ratios for $\mathrm{Pb}(\mathrm{II}) / \mathrm{Tl}(\mathrm{I})$ and $\mathrm{Cu}(\mathrm{II}) / \mathrm{Tl}(\mathrm{I})$ of 2000 and 400, respectively, did not show interference thus duplicating and quadruplicating the concentrations of $\mathrm{Pb}(\mathrm{II})$ and $\mathrm{Cu}(\mathrm{II})$, respectively above which interference with $\mathrm{Tl}(\mathrm{I})$ occurs, as compared to the standard method published. The proposed methodology has a detection limit of $2 \mu \mathrm{g} / \mathrm{L}$, a quantification limit of $7 \mu \mathrm{g} / \mathrm{L}$, and a linear range between 2.3 and $20 \mu \mathrm{g} / \mathrm{L}$. Enriched Tl solutions of 0.5, 2.5 and $9 \mu \mathrm{g} / \mathrm{L}$ showed excellent recoveries. The methodology was applied to extractions of contaminated soil samples with $\mathrm{Tl}$ contents from 0.05 to $3.2 \mathrm{mg} / \mathrm{kg}$.
\end{abstract}

Palabras clave: voltamperometría, interferencia, análisis de trazas, talio, EDTA, muestras de suelo 


\title{
RESUMEN
}

\begin{abstract}
Se optimizaron las condiciones para la determinación de talio (I) en presencia de plomo (II) y cobre (II) sin separación preliminar de estos iones, a partir de un método ya establecido de voltametría de redisolución anódica diferencial de pulsos, usando un electrodo colgante de gota de mercurio y un electrodo de $\mathrm{Ag} / \mathrm{AgCl}$. Desafortunadamente, la actividad electroquímica del plomo (II) interfiere en la determinación de talio (I), pero la adición del agente complejante EDTA $0.1 \mathrm{M}(\mathrm{a} \mathrm{pH}=4.6)$ provoca un desplazamiento del pico del plomo (II) a valores más negativos, a un potencial de deposición óptimo de $-0.550 \mathrm{~V}$. Sin embargo, el pico de reducción del $\mathrm{Cu}$ (II) también se desplaza al complejarse con el agente EDTA, acercándose al del Tl(I) y convirtiéndose en un ion interferente. El tiempo de deposición y la velocidad de barrido que se encontraron óptimos para la determinación fueron de $30 \mathrm{~s}$ y $10 \mathrm{mV} / \mathrm{s}$, respectivamente. Bajo estas condiciones se encontró que relaciones máximas de concentración $\mathrm{Pb}(\mathrm{II}) / \mathrm{Tl}(\mathrm{I})$ y $\mathrm{Cu}(\mathrm{II}) /$ $\mathrm{Tl}(\mathrm{I})$ de 2000 y 400, respectivamente, no interfieren, permitiendo duplicar y cuadruplicar la concentración de $\mathrm{Pb}$ (II) y de $\mathrm{Cu}(\mathrm{II})$, respectivamente, que no interfieren con el $\mathrm{Tl}(\mathrm{I})$ respecto al método estándar publicado. La metodología propuesta tiene un límite de detección de $2 \mu \mathrm{g} / \mathrm{L}$, un límite de cuantificación de $7 \mu \mathrm{g} / \mathrm{L}$ y un intervalo lineal entre 2.3 y $20 \mu \mathrm{g} / \mathrm{L}$. Soluciones de Tl enriquecidas con $0.5,2.5$ y $9 \mu \mathrm{g} / \mathrm{L}$ mostraron excelentes porcentajes de recuperación. Se aplicó la metodología en diferentes extractos de suelos contaminados cuyo contenido de Tl varió de 0.05 a $3.2 \mathrm{mg} / \mathrm{kg}$.
\end{abstract}

\section{INTRODUCTION}

Thallium (Tl) is a highly toxic post-transitional metal that is more toxic to mammals than any other element or inorganic species, including $\mathrm{Hg}, \mathrm{Cd}, \mathrm{Pb}$, $\mathrm{As}, \mathrm{Cu}$, and $\mathrm{Zn}$ (Peter and Viraraghavan 2005). For this reason $\mathrm{Tl}$ is considered a priority pollutant by the US-EPA (Keith and Telliard 1979) and other countries, including Mexico, and its quantification is necessary for a precise evaluation of the generalized potential toxicity risk by metals in the environment (Galván-Arzate and Santamaría 1998, Cvjetko et al. 2010). However, its concentration in environmental samples is considerably lower than that of other toxic metals and metalloids, but given its high toxicity it is possible that in many cases these low concentrations are potentially toxic. Despite the fact that maximum permissible $\mathrm{Tl}$ levels have been established in water and soils in regulatory agencies of various countries, such as Spain, France, China, and Mexico, these are not consistent and differ in values considerably; or in the case of Mexico, they are not complete because soils are regulated but water is not. In general, the geochemical and environmental toxicity information of this element is sufficiently deficient to not fully justify the particular permissible limits selected.

Non polluted surface waters generally exhibit $\mathrm{Tl}$ concentrations below $10 \mathrm{ng} / \mathrm{L}$ (Lukaszewski and Piela 1996) and the concentrations of natural $\mathrm{Tl}$ in soils range from 0.08 to $1.5 \mu \mathrm{g} / \mathrm{g}$ (Wenqi et al. 1992, von Laar et al. 1994, Tremel et al. 1997); although some sites have been reported with much higher natural $\mathrm{Tl}$ concentrations, e.g., of up to $55 \mu \mathrm{g} / \mathrm{g}$ (Morvan North frontier, France [Tremel et al. 1997]).

Soils located in close proximity to $\mathrm{Zn}$ and $\mathrm{Pb}$ smelters show $\mathrm{Tl}$ concentrations that are much higher (Gómez-González et al. 2015, Liu et al. 2016, CruzHernández et al. 2018), and its aqueous mobility is a crucial factor to elucidate its potential toxic effect. This mobility can be determined by sequential extraction procedures employing extracting solutions that may provide information on the geochemical/ mineralogical fractions that this metallic ion is associated to (Cruz-Hernández et al. 2018). However, quantification of $\mathrm{Tl}$ in the extracts is problematic due to its low concentrations and numerous interfering agents present, and this may explain the relatively few reports that exist on the mobility of $\mathrm{Tl}$ in soils. For this, analytical methods with sufficiently low detection limits and relatively controlled interferences are required.

There are electrochemical methods capable of quantifying thallium. For example, differential pulse voltammetry (DPV), also differential pulse polarography (DPP), and differential pulse anodic stripping voltammetry (DPASV). The first is a voltammetry method used to make electrochemical measurements and a derivative of linear sweep voltammetry or staircase voltammetry with a series of regular voltage pulses superimposed on the potential linear sweep or stairsteps (Laborda et al. 2014). The current is measured immediately before each potential change, 
and the current difference is plotted as a function of potential. This technique has been used to quantify thallium (Wang et al. 2013) but does not offer low enough detection limits as compared with DPASV.

The DPASV when using a hanging mercury drop electrode (HMDE) offers detection limits that are adequate for many metallic ions, including $\mathrm{Tl}$ (Batley and Florence 1975, Lukaszewski et al. 1980, Ciszewski et al.1997, Krasnodebska-Ostrega and Stryjewska 2004, Espinosa-Castellón and Alvarado-Gámez 2012). This DPASV technique is a voltammetric method for quantitative determination of specific ionic species. The analyte of interest is electroplated on the working electrode during a deposition step, and oxidized from the electrode during the stripping step. The current is measured during the stripping step. The oxidation of species is registered as a peak in the current signal at the potential at which the species begins to be oxidized. The stripping step can be either linear, staircase, squarewave, or pulse. Recently in the literature the use of other electrodes for thallium determination has been reported, such as bismuth bulk annular band electrode (BiABE) (Wegial et al. 2016) and a hanging galinstan drop electrode (HGDE) (Surmann and Channaa 2015).

The equipment used in this technique is relatively cheaper and is portable with shorter analysis times than other methods with similar detection limits, such as inductively coupled plasma with mass spectrometry (ICP-MS). Additionally, it is oxidation stateselective, as opposed to techniques such as the latter, which measure total $\mathrm{Tl}(=\mathrm{Tl}[\mathrm{I}]+\mathrm{Tl}[\mathrm{III}])$.

The main interference in $\mathrm{Tl}$ determination by DPASV is lead (II) (Lukaszewski et al. 1992). The voltamperometric peak of $\mathrm{Pb}(\mathrm{II})(-0.38 \mathrm{~V})$ appears very near the $\mathrm{Tl}(\mathrm{I})$ peak $(-0.44 \mathrm{~V})$. However, application of a $\mathrm{Pb}$ (II) complexing agent, which does not complex Tl(I), such as EDTA (Wegial et al. 2016) reduces this effect because it causes a shift of the $\mathrm{Pb}$ (II) peak to more negative potentials $(-0.5$ to -0.6 V) (Ngila et al. 2005), which allows a thousand-fold $\mathrm{Pb}$ (II) tolerance in excess of $\mathrm{Tl}(\mathrm{I})$ (Dhaneswar and Zarparkar 1980, Lukaszewski et al. 2003).

However, in the simultaneous presence of $\mathrm{Cu}$ (II) and $\mathrm{Pb}$ (II) at high concentrations, as is the case in mine and metallurgical-affected environments, because $\mathrm{Cu}(\mathrm{II})$ is also complexed with EDTA, the new $\mathrm{Cu}$ (II)-EDTA peak, which originally in its free form occurs far from the Tl peak $(0.0 \mathrm{~V})$, decreases to more reducing potentials $(-0.30$ to $-0.40 \mathrm{~V}$, at $\mathrm{pH}$ 4.6) (Metrohm 1993), and to $-0.5 \mathrm{~V}$ at $\mathrm{pH} 7$ (Wang et al. 2008), creating thus a new interference for Tl(I) originally not present. Furthermore, the $\mathrm{Cu}(\mathrm{II})$-EDTA affinity constant ( $\log \mathrm{K}=10.23$ at $\mathrm{pH} 4.6)$ is larger than that of the $\mathrm{Pb}(\mathrm{II})$-EDTA complex $(\log \mathrm{K}=9.46$ at $\mathrm{pH}$ 4.6) (Wanninen and Ingman 1987), leading to a more favorable formation for $\mathrm{Cu}$ (II) than for $\mathrm{Pb}$ (II), and thus a high excess of EDTA must be added to ensure all $\mathrm{Pb}(\mathrm{II})$ is bound.

In the voltamperometric methods literature, other working electrodes are reported that are usually very expensive in comparison to the mercury electrode, which simultaneously determine $\mathrm{Tl}, \mathrm{Pb}$ and $\mathrm{Cu}$, such as $\mathrm{NiCo}_{2} \mathrm{O}_{4}$ porous nanoplates (Dong and Zhang 2017) and the bismuth-film electrode (BiFE) (Carvalho et al. 2007). However, no specific details are reported about the behavior of the interferences with these electrodes when both ions are present simultaneously, as for example, what are the maximum $\mathrm{Pb}$ (II)/Tl(I) y $\mathrm{Cu}(\mathrm{II}) / \mathrm{Tl}$ (I) ratios allowed for accurate $\mathrm{Tl}(\mathrm{I})$ determinations, and what the detection limits are under these conditions. The DPASV method to eliminate the $\mathrm{Pb}$ (II) interference by using EDTA has been pre-optimized, as mentioned above (Metrohm 1993), but further optimization is required to reliably quantify $\mathrm{Tl}(\mathrm{I})$ in the presence of both $\mathrm{Pb}$ (II) and $\mathrm{Cu}(\mathrm{II})$ ions, while producing stable and reproducible $\mathrm{Tl}$ signals, low detection limits, and minimization of the interferent action of these ions. Therefore, the goal of the present work was to study the effects (and perform a fine-tuning optimization) of the following conditions in the previously reported DPASV method using an HMDE: (i) the deposition potential, (ii) the deposition time, (iii) the scan rate, and (iv) the pulse amplitude, to maximize $\mathrm{Tl}$ quantification in the presence of the two interfering cations $\mathrm{Pb}(\mathrm{II})$ and $\mathrm{Cu}(\mathrm{II})$. This will be highly useful for quantification work of thallium in environments contaminated with multiple metals, and will be demonstrated with an application example in real Tl-contaminated soils.

\section{MATERIALS AND METHODS}

\section{Equipment}

The voltamperometric determination of $\mathrm{Tl}(\mathrm{I})$ in the presence of $\mathrm{Pb}(\mathrm{II})$ and $\mathrm{Cu}(\mathrm{II})$ was performed with a trace metal analyzer (797VA Computrace, Metrohm AGLtd, Switzerland), which consists of a working hanging mercury drop electrode (HMDE) (Metrohm, Switzerland), an auxiliary platinum (Pt) electrode, and a $\mathrm{Ag} / \mathrm{AgCl} / \mathrm{KCl}(3 \mathrm{~mol} / \mathrm{L})$ reference electrode (Korolczuk 1999). The measuring electrochemical cell is a glass container of $80 \mathrm{~mm}$ of diameter and of height, of $20.1 \mathrm{~mL}$ capacity, which is covered 
by a teflon cap containing holes through which the corresponding electrodes are introduced, and for nitrogen gas bubbling.

\section{Reagents}

MILLI-Q water was used for all solutions prepared, with an electrical conductivity below 18.2 $\mathrm{M} \Omega . \mathrm{cm}$.

A pH buffer solution of 4.6 was used by mixing $2 \mathrm{~mol} / \mathrm{L} \mathrm{CH}_{3} \mathrm{COOH}$ and $1 \mathrm{~mol} / \mathrm{L} \mathrm{NH}_{4} \mathrm{OH}$ (both from Fluka \&Poch, of $99 \%$ purity).

An aqueous solution of $0.201 \mathrm{~mol} / \mathrm{L}$ EDTA was prepared, at its solubility limit from its di-sodium salt (J.T. Baker, $100.3 \%$ purity). In order to prepare $\mathrm{Tl}(\mathrm{I})$, $\mathrm{Pb}$ (II), and $\mathrm{Cu}$ (II) standards at different concentrations, standard stock solutions were used of 10000 $\mathrm{mg} / \mathrm{L}$ for Tl(I) and of $1000 \mathrm{mg} / \mathrm{L}$ for the other two, all from Fluka.

The reagents used for investigating the complexing effect on $\mathrm{Cu}$ were $\mathrm{KCl}$ (J.T. Baker, 99.0-100.5 \%), $\mathrm{KNO}_{3}$ (J.T. Baker, $99 \%$ ), $\mathrm{K}_{2} \mathrm{SO}_{4}$ (J.T. Baker, $99 \%$ ) and $0.1 \mathrm{M} \mathrm{NaOH}$ (MACRON, $98 \%$ ).

\section{Procedure}

The analysis technique implemented in this work was optimized from that described in the procedures manual of Metrohm, referenced as AB074 (Metrohm 1993) (adapted from Dhaneswar and Zarparkar 1980) to determine Tl(I) by DPASV using a HMDE. The general procedure is described as follows: $10 \mathrm{~mL}$ of sample and $10 \mathrm{~mL}$ of the $0.201 \mathrm{M}$ EDTA solution were added to the electrochemical cell, both using volumetric PYREX pipets, as well as $0.1 \mathrm{~mL}$ of acetate/ammonium buffer ( $\mathrm{pH} 4.6$ ) to ensure a peak of maximum current for thallium (Batley and Florence 1975, Mahesar et al. 2010). Dissolved oxygen was removed from this solution by bubbling nitrogen gas for 5 min just prior to the voltammetric measurement. The Tl(I) concentration used for most optimization tests was $10 \mu \mathrm{g} / \mathrm{L}$.

The influence of the following parameters on the response of the reduction current intensity for the electrodeposition of thallium on the HMDE was studied: deposition potential, deposition time, scan rate, and pulse amplitude, by starting from initial values as proposed by the AB074 Metrohm procedure (Dhaneswar and Zarparkar [1980], Lukaszewski et al. [2003]) (deposition potential $=-0.700 \mathrm{~V}$, deposition time $=60 \mathrm{~s}$, scan rate $=20 \mathrm{mV} / \mathrm{s}$, pulse amplitude $=$ $0.050 \mathrm{~V})$. This was done in the presence of $2,10,20$ and $25 \mathrm{mg} / \mathrm{L} \mathrm{Pb}(\mathrm{II})$, and/or 2, 4 and $5 \mathrm{mg} / \mathrm{L} \mathrm{Cu}(\mathrm{II})$. The voltamperograms were registered between -0.9 and $0.4 \mathrm{~V}$ in the differential pulse mode. $\mathrm{Tl}(\mathrm{I})$ was quantified by plotting a calibration curve of current intensity vs. concentration in an interval from 2 to $20 \mu \mathrm{g} / \mathrm{L}$. The following validation parameters were determined: detection limit, quantification limit, sensitivity, coefficient of variation and percentage of recovery according to the method of Taylor (1987), for which eight independent replicates were made.

\section{Mobile thallium in real samples}

Sieved soil $(0.5 \mathrm{~g})$ was stirred for $16 \mathrm{~h}$ with 20 $\mathrm{ml} 0.11 \mathrm{M}$ acetic acid (J.T. Baker, ULTREX, Ultrapure Reagent) at room temperature and $\mathrm{pH} 2.85$ to determine the most mobile $\mathrm{Tl}$ fraction from soils, tailings and soil contaminated with mining waste, after the completely soluble fraction, taking into account the sequential extraction method proposed by the European Bureau of Reference (BCR), modified and described by Vaněk et al. (2010a, b). The thallium fraction extracted here constitutes the carbonate bound, proton-exchangeable, and partially bound $\mathrm{Tl}$ to poorly-crystalline Mn oxides (Vaněk et al. 2010a). After an equilibration time of $2 \mathrm{~h}$, the samples were centrifuged for $10 \mathrm{~min}$ at $5000 \mathrm{rpm}$ with a centrifuge (PrO-Research from Centurion Scientific Ltd), then filtered using Amicon ultrafilters (Amicon Ultra-15 $10 \mathrm{~K}$, Millipore, MA) porous cellulose membranes with a pore size of $0.05 \mu \mathrm{m}$. Extraction was done in triplicate.

\section{RESULTS AND DISCUSSION}

\section{Influence of the presence of $\mathrm{Pb}$ (II) and $\mathrm{Cu}$ (II) in} the determination of Tl(I), in the absence of EDTA

$\mathrm{Pb}$ (II) shows an electrochemical reduction peak $(-0.38 \mathrm{~V})$ that is found very close to that of Tl(I) $(-0.44 \mathrm{~V})$, therefore they interfere with each other, as illustrated in figure 1a for a concentration one thousand times higher in $\mathrm{Pb}(\mathrm{II})$. Because the peaks of both species almost superimpose, the method labels the peak at $-0.38 \mathrm{~V}$ as "unknown", and the $\mathrm{Tl}(\mathrm{I})$ peak appears as a shoulder at $-0.44 \mathrm{~V}$. In the case of $\mathrm{Cu}$ (II) its reduction potential is found far from that of $\mathrm{Tl}(\mathrm{I})$ towards more oxidizing potentials $(0.0 \mathrm{~V})$ (Fig. 1b), which allows the determination of high $\mathrm{Cu}(\mathrm{II})$ concentrations without interfering with the $\mathrm{Tl}(\mathrm{I})$ quantification.

The effect of different supporting electrolyte anions was investigated on the complexing effects and thus on the reduction potential of $\mathrm{Cu}(\mathrm{II})$, using $\mathrm{KCl}, \mathrm{KNO}_{3}$ and $\mathrm{K}_{2} \mathrm{SO}_{4}$. The $\mathrm{pH}$ of the system was set at 4.6 with $0.1 \mathrm{M} \mathrm{NaOH}$ to ensure that the $\mathrm{Tl}(\mathrm{I})$ peak current reached its maximum value, and to make 


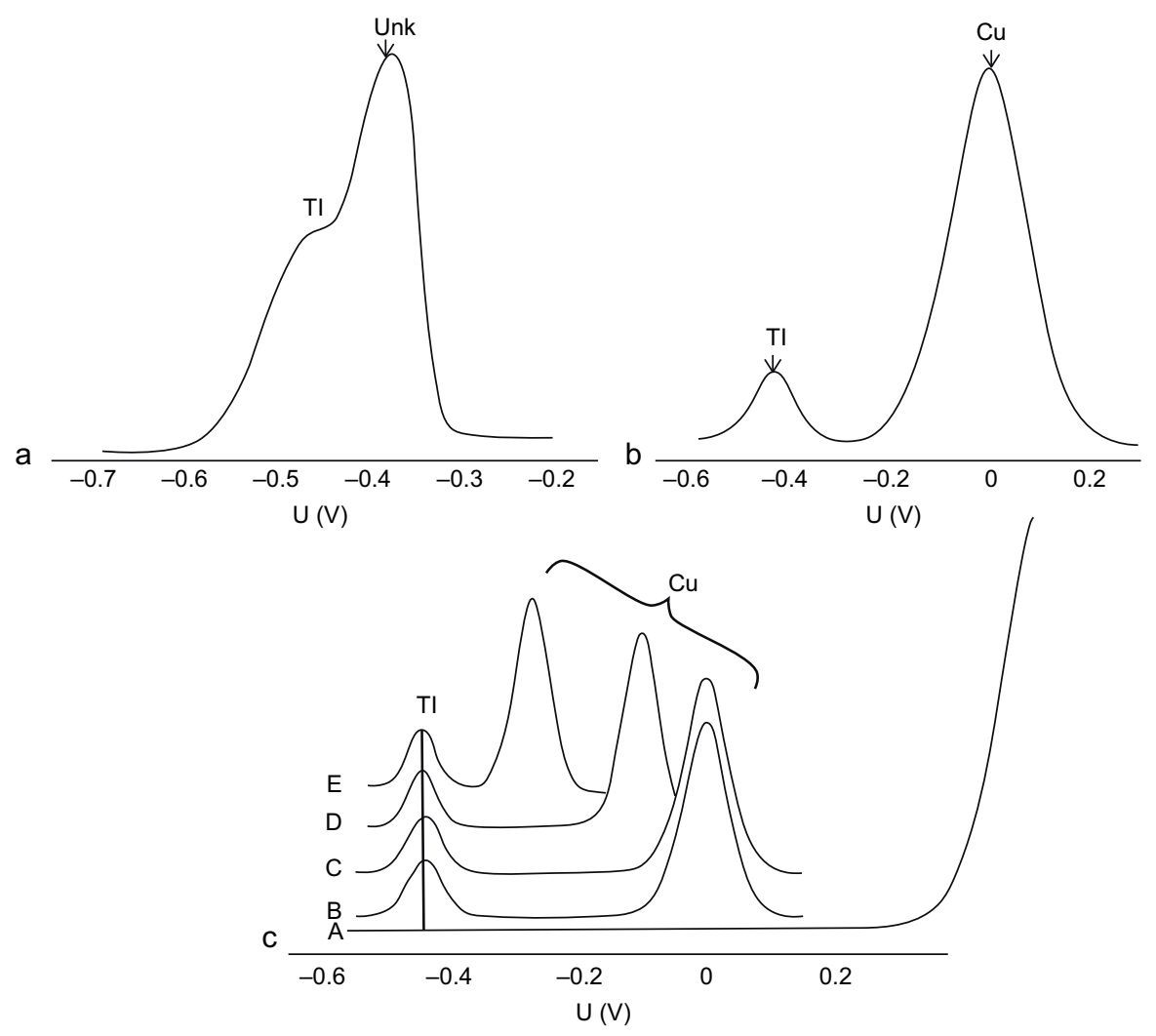

Fig. 1. (a) Influence of the presence of $10 \mathrm{mg} / \mathrm{L} \mathrm{Pb}(\mathrm{II})$, (b) of $500 \mu \mathrm{g} / \mathrm{L} \mathrm{Cu}$ (II) (b) (without electrolytes), and (C) of various electrolytes, in the differential pulse anodic stripping voltammetry (DPASV) potential (U) signal of $10 \mu \mathrm{g} / \mathrm{L} \mathrm{Tl}(\mathrm{I})$ in the absence of ethylenediaminetetraacetic acid (EDTA) at $\mathrm{pH} 4.6$ (A: Blank of $10 \mathrm{~mL} 1 \mathrm{M} \mathrm{KNO}_{3}$ and 3.3 $\times 10^{-3} \mathrm{M} \mathrm{K}_{2} \mathrm{SO}_{4} ; \mathrm{B}: 1 \mathrm{M} \mathrm{KNO}_{3} ; \mathrm{C}: 3.3 \times 10^{-3} \mathrm{M} \mathrm{K}_{2} \mathrm{SO}_{4}(\mathrm{pH}=4)$; and D: $0.6 \mathrm{M} \mathrm{KCl}$; E: $1 \mathrm{M} \mathrm{KCl}$ ). Deposition potential $-0.700 \mathrm{~V}$, deposition time $60 \mathrm{~s}$, scan rate $20 \mathrm{mV} / \mathrm{s}$, pulse amplitude $0.050 \mathrm{~V}$

the results comparable to those in the presence of the acetate buffer used further along. The results are shown in the voltamperogram sequence in figure 1c.

The $\mathrm{Tl}(\mathrm{I})(10 \mu \mathrm{g} / \mathrm{L})$ reduction peak in the presence of $\mathrm{Cu}(\mathrm{II})(500 \mu \mathrm{g} / \mathrm{L})$ was not altered with $1 \mathrm{M}$ $\mathrm{KNO}_{3}$ as electrolyte since the $\mathrm{Cu}$-nitrate complex is very weak (Fig. 1c [B]). The same was observed with sulfate (Fig. 1c [C]) (here the $\mathrm{K}_{2} \mathrm{SO}_{4}$ concentration used was $3.3 \times 10^{-3} \mathrm{M}$ at $\mathrm{pH}=4$ in order to simulate the sulfate concentration in a typical mining environment with acid mine drainage (Harris et al. 2003]).

When using $\mathrm{KCl}$, the $\mathrm{CuCl}_{4}{ }^{-2}$ complex formation is highly favored ( $\log K=5.6)$ (Ritchie 2004). The characteristic reduction potential on a $\mathrm{Hg}$ electrode according to thermodynamic calculations is $\mathrm{E}^{0}=$ $-0.05 \mathrm{~V}$ (equation 1). The $\mathrm{Cu}(\mathrm{II})$ voltamperometric signal is progressively shifted to more negative potentials as chloride concentration is increased, to
$-0.120 \mathrm{~V}$ with $0.6 \mathrm{M} \mathrm{KCl}$ (Fig. 1c [D]), and up to $-0.270 \mathrm{~V}$ with $1 \mathrm{M} \mathrm{KCl}$ (Fig. 1c [E]).

$\mathrm{CuCl}_{4}{ }^{2-}+2 \mathrm{e}^{-} \rightleftharpoons \mathrm{Cu}^{0}+4 \mathrm{Cl}^{-}$

According to the calculation of the equilibrium potential $\left(E_{\text {eq }}\right)$ shown in equation 2 , its dependence on the chloride concentration is evident, producing a larger shift in the $\mathrm{Cu}$ (II) signal as the concentration of this anion is increased, even if electrochemical equilibrium is not reached.

$\left.\mathrm{E}_{\mathrm{eq}}=\mathrm{E}^{0}+0.059 / 2 \log \left(\left[\mathrm{CuCl}_{4}{ }^{2-}\right]\right) /\left(\left[\mathrm{Cl}^{-}\right]^{4}\right]\right)$

In contrast, the presence of chloride affects very little both the $\mathrm{Tl}(\mathrm{I})$ and $\mathrm{Pb}$ (II) signals, because the corresponding formation constants for their predominant complexes are much smaller ( $\mathrm{TlCl}$ [aq] $\log \mathrm{K}=0.51$, 
$\mathrm{PbCl}_{2}$ [aq] Log $\mathrm{K}=2.20$, MINEQL [Schecher and McAvoy 1992]). If the sample does not contain chloride, it is preferable to use the acetate buffer to attain the $\mathrm{Cu}(\mathrm{II})$ peaks with no altered potential $(0.00-0.05$ $\mathrm{V})$, minimizing its interfering potential with the Tl(I) determination.

\section{Influence of $\mathrm{Pb}(\mathrm{II})$ and $\mathrm{Cu}(\mathrm{II})$ in the determina- tion of $\mathrm{Tl}(\mathrm{I})$, in the presence of EDTA}

EDTA is a hexadentate and tetravalent anionic ligand that provides a chelating effect that favors the formation of a $\mathrm{Pb}(\mathrm{II})$-EDTA soluble complex (Chulsung 1996), which may even act on solid Pb(II) compounds. Given the EDTA $\left(\mathrm{Y}^{4-}\right)$ protonation constants, at the working $\mathrm{pH}$ of 4.6 the predominant species is biprotonated $\left(\mathrm{H}_{2} \mathrm{Y}^{2-}\right)$, as shown in equation 3 for its complexation with $\mathrm{Pb}^{2+}(\log \mathrm{K}=9.46$ [Wanninen and Ingman 1987]).
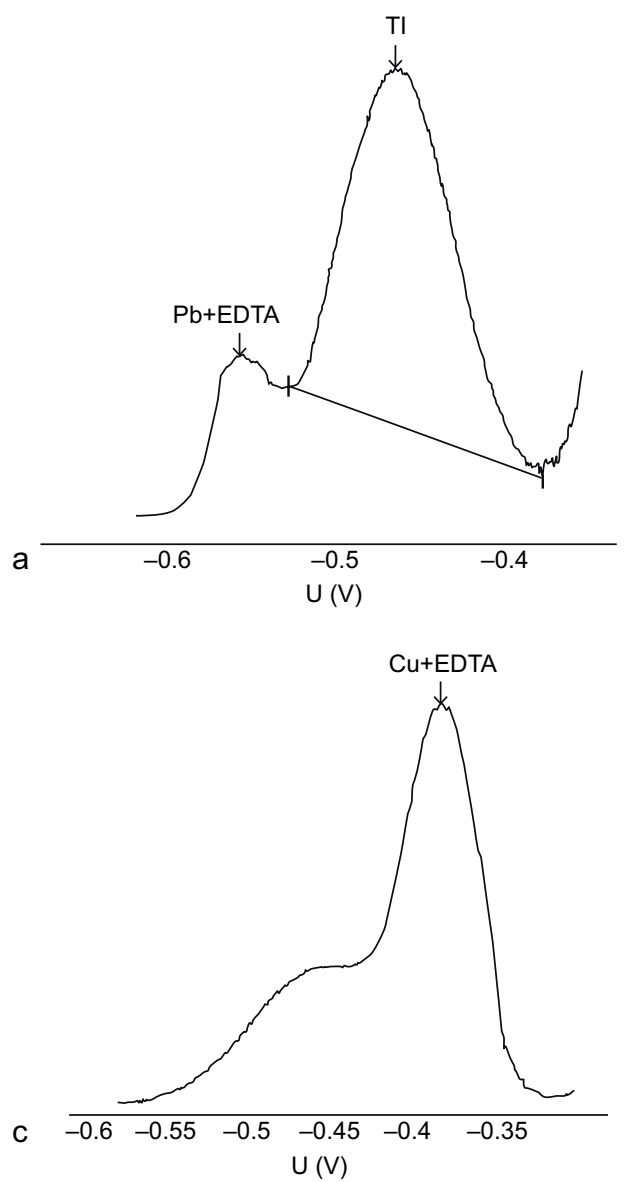

$\mathrm{Pb}^{2+}+\mathrm{H}_{2} \mathrm{Y}^{2-} \rightleftharpoons \mathrm{PbY}^{2-}+2 \mathrm{H}^{+}$

The $\mathrm{Pb}(\mathrm{II})-\mathrm{EDTA}^{2-}$ complex shows a reduction potential in the interval -0.5 to $-0.6 \mathrm{~V}$ vs. the $\mathrm{Ag} /$ $\mathrm{AgCl}$ reference electrode (Ngila et al. 2005), which is considerably more negative than that of $\mathrm{Tl}(\mathrm{I})$, which in turn does not form EDTA complexes, so it maintains its peak at the same potential $(-0.44$ $\mathrm{V})$, effectively removing the interference of $\mathrm{Pb}(\mathrm{II})$ illustrated in the previous section (Fig. 2a).

In the same manner as the shift in the $\mathrm{Cu}$ (II) signal in the presence of chloride was described (equation 2), the specific concentration of EDTA added to the solution affects the shift in the $\mathrm{Pb}$ (II) signal, and to achieve the highest possible shift, a large EDTA concentration $(0.1 \mathrm{M})$ is preferred. However, despite the large shift expected, a very large excess of $\mathrm{Pb}$ (II) will eventually cause the large $\mathrm{Pb}(\mathrm{II})$-EDTA signal tail
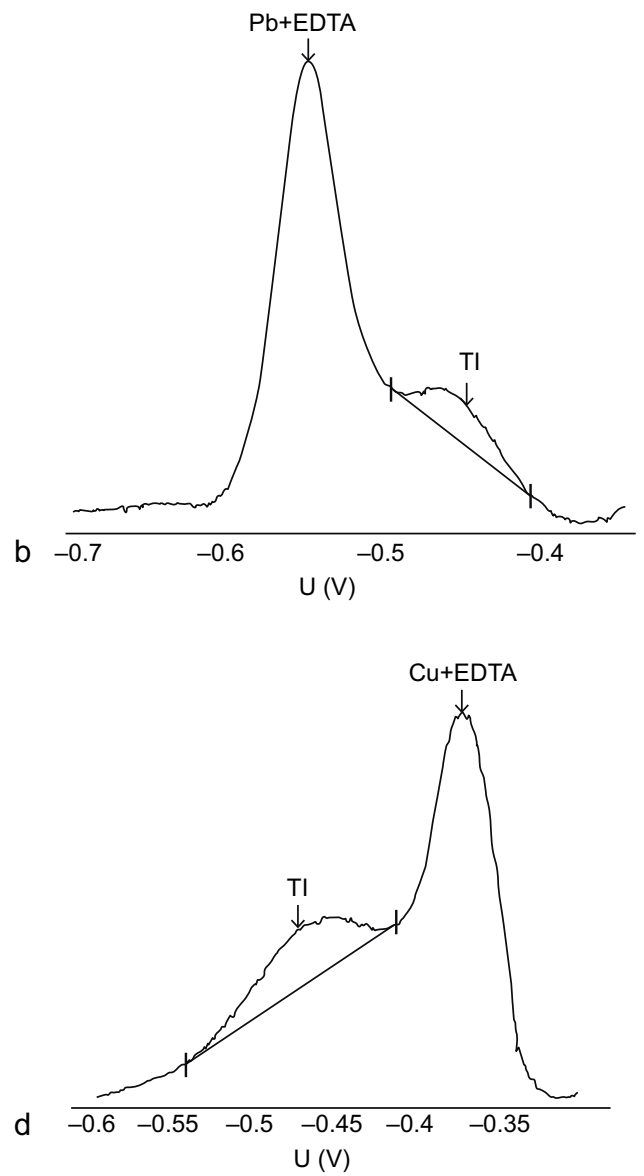

Fig. 2. Influence of the $\mathrm{Pb}$ (II) concentration: (a) $10 \mathrm{mg} / \mathrm{L}$, (b) $20 \mathrm{mg} / \mathrm{L}$, and $\mathrm{Cu}$ (II): (c) $5 \mathrm{mg} / \mathrm{L}$, (d) $2 \mathrm{mg} / \mathrm{L}$, in the differential pulse anodic stripping voltammetry (DPASV) potential (U) signal of $10 \mu \mathrm{g} / \mathrm{L}$ $\mathrm{Tl}(\mathrm{I})$ in the presence of $0.1 \mathrm{M}$ ethylenediaminetetraacetic acid (EDTA). Intensity signal scales are arbitrary and vary among graphs. $\mathrm{pH}=4.6$. Deposition potential $-0.700 \mathrm{~V}$, deposition time $60 \mathrm{~s}$, scan rate $20 \mathrm{mV} / \mathrm{s}$, pulse amplitude $0.050 \mathrm{~V}$ 
to invade the $\mathrm{Tl}(\mathrm{I})$ signal, preventing their adequate separation (Fig. 2b).

Unfortunately, the presence of $\mathrm{Cu}(\mathrm{II})$ ions, which also complex with EDTA $(\log \mathrm{K}=10.23$ [Wanninen and Ingman 1987]), interfere in the Tl(I) determination because the analytical $\mathrm{Cu}$ (II)-EDTA signal shifts to negative potentials and approaches the Tl(I) signal (Fig. 2c). This interference does not occur for sufficiently small $\mathrm{Cu}$ (II) concentrations (Fig. 2d).

\section{Influence of the scan rate on the separation of $\mathrm{Tl}(\mathrm{I})$ y $\mathrm{Pb}$ (II) signals}

In order to separate as much as possible the $\mathrm{Tl}(\mathrm{I})$ signal from those of $\mathrm{Pb}(\mathrm{II})$ and $\mathrm{Cu}(\mathrm{II})$, the scan rate was varied keeping constant the amplitude pulse at $0.050 \mathrm{~V}$ (Dhaneswar and Zarparkar 1980, Metrohm 1993, Lukaszewski et al. 2003). A lower amplitude produced too much noise, and higher amplitudes generated higher current intensities (Fig. 3d), but also loss of resolution and increase in the current load, therefore the value of $0.050 \mathrm{~V}$ originally proposed in the Metrohm method was deemed the adequate amplitude (Bond 1980).

In Figure 3 the voltamperograms obtained at three different scan rates are shown: at $5 \mathrm{mV} / \mathrm{s}$ (Fig. 3a) the $\mathrm{Pb}(\mathrm{II})$-EDTA signal separates well (reaching background values before the $\mathrm{Tl}[\mathrm{I}]$ signal appears) but an asymmetric widening occurs and the Tl(I) signal noise increases. At $10 \mathrm{mV} / \mathrm{s}$ (Fig. 3b), the signals separate even better with narrower peaks and the noise decreases; while at $20 \mathrm{mV} / \mathrm{s}$ (Fig. 3c) the signals do not separate as well. At this latter speed but increasing the pulse amplitude above $0.07 \mathrm{~V}$ (Fig. 3d), the signals widen further, making them unidentifiable by the program. Therefore, the optimal speed chosen was $10 \mathrm{mV} / \mathrm{s}$, i.e., half of that recommended by the standard method (Dhaneswar and Zarparkar 1980, Metrohm 1993, Lukaszewski et al. 2003).
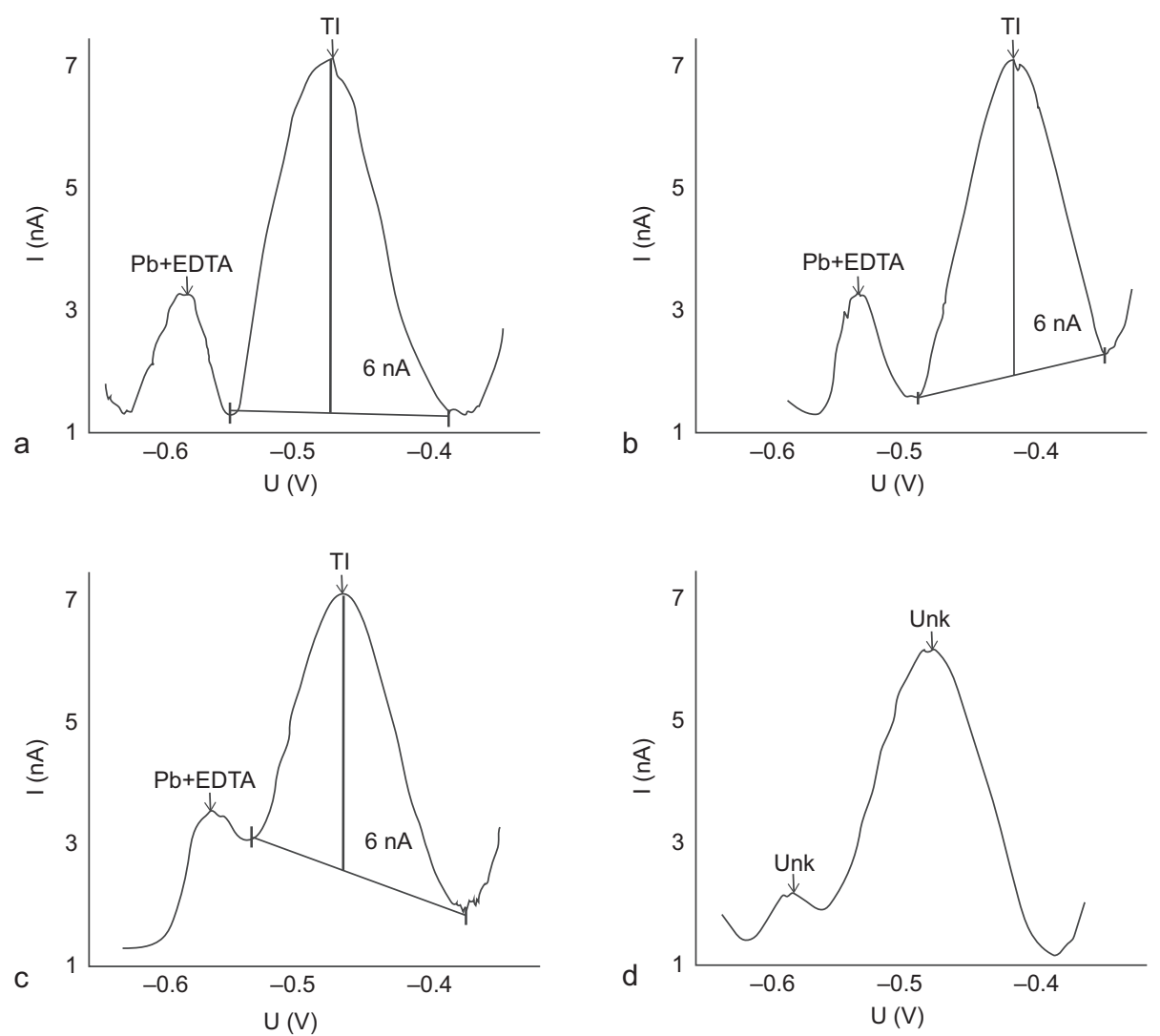

Fig. 3. Effect of the scan rate on the separation of differential pulse anodic stripping voltammetry (DPASV) potential (U) signals of Pb(II) + EDTA and Tl(I), $10 \mu \mathrm{g} / \mathrm{L} \mathrm{Tl}(\mathrm{I})+10 \mathrm{mg} / \mathrm{L}$ $\mathrm{Pb}$ (II) at $0.05 \mathrm{~V}$ pulse amplitude: (a) $\mathrm{v}=5 \mathrm{mV} / \mathrm{s}$, (b) $\mathrm{v}=10 \mathrm{mV} / \mathrm{s},(\mathrm{c}) \mathrm{v}=20 \mathrm{mV} / \mathrm{s}$, (d) $\mathrm{v}=20 \mathrm{mV} / \mathrm{s}(0.07 \mathrm{~V}$ pulse amplitude). Deposition potential $-0.700 \mathrm{~V}$, deposition time $60 \mathrm{~s}$, pulse amplitude $0.050 \mathrm{~V}$ in all, except $0.07 \mathrm{~V}$ in $\mathrm{d}$ 
Influence of deposition time and potential on the $\mathrm{Tl}(\mathrm{I})$ signal in the presence of $\mathrm{Pb}$ (II) and $\mathrm{Cu}(\mathrm{II})$

One of the instrumental parameters that may increase the sensitivity of a voltamperometric method is the deposition time. Under normal conditions, the magnitude of the electrochemical signal tends to be directly proportional to this time. In general, the recommended deposition times should be no longer than the minima required to obtain well defined and easily measurable peaks, in order to maintain short analysis times.

Deposition times from 15 to $60 \mathrm{~s}$ at a deposition potential of $-0.700 \mathrm{~V}$ (Metrohm 1993) (adapted from Dhaneswar and Zarparkar 1980) were investigated (Fig. 4). This study revealed that peak signal for each metal increased linearly from 15 to $30 \mathrm{~s}$ of deposition, reaching a maximum current in the Tl(I) peak of 3.24 $\mathrm{nA}$ at $30 \mathrm{~s}$. While at $15 \mathrm{~s}$ deposition the $\mathrm{Pb}$ (II)-EDTA signal is zero, and the largest difference in signals is obtained, where the Tl(I) signal is relatively the largest, unfortunately, the $\mathrm{Tl}(\mathrm{I})$ signal appears very noisy at this low deposition time, so we chose a 30 s deposition time as the optimum, given also that a maximum $\mathrm{Tl}(\mathrm{I})$ peak is attained. With times above $30 \mathrm{~s}$ peak current values increased for $\mathrm{Cu}(\mathrm{II})$-EDTA above those of $\mathrm{Tl}(\mathrm{I})$, and the same occurred for the $\mathrm{Pb}$ (II)-EDTA peak current above ca. $45 \mathrm{~s}$. Above $30 \mathrm{~s}$, also the absolute value of the $\mathrm{Tl}(\mathrm{I})$ peak decreased, possibly from metal saturation on the surface of the electrode (Inam et al. 1999). Therefore, $30 \mathrm{~s}$ was selected as the optimal deposition time to minimize simultaneous $\mathrm{Cu}(\mathrm{II})$-EDTA and $\mathrm{Pb}(\mathrm{II})$-EDTA interferences.

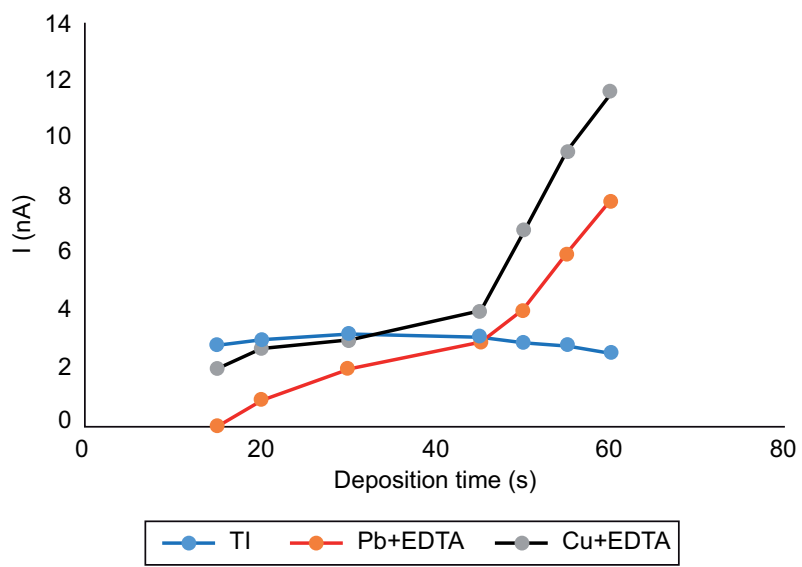

Fig. 4. Effect of deposition time of differential pulse anodic stripping voltammetry (DPASV) potential (U) signals for $\mathrm{Tl}(\mathrm{I})$ on the peak current amplitudes of $10 \mu \mathrm{g} / \mathrm{L} \mathrm{Tl}(\mathrm{I})+20$ $\mathrm{mg} / \mathrm{L} \mathrm{Pb}(\mathrm{II})+3 \mathrm{mg} / \mathrm{L} \mathrm{Cu}$ (II) and $0.1 \mathrm{M}$ ethylenediaminetetraacetic acid (EDTA), $\mathrm{pH}$ 4.6. Deposition potential $-0.700 \mathrm{~V}$, scan rate $10 \mathrm{mV} / \mathrm{s}$, pulse amplitude $0.050 \mathrm{~V}$
The values of the peak currents were taken at the corresponding reduction potentials for each system, i.e., $-0.44,-0.55$, and -0.30 to $-0.35 \mathrm{~V}$, for $\mathrm{Tl}(\mathrm{I})$, $\mathrm{Pb}(\mathrm{II})-\mathrm{EDTA}$, and $\mathrm{Cu}(\mathrm{II})-\mathrm{EDTA}$, respectively.

Deposition potential values were evaluated between -0.700 and $-0.500 \mathrm{~V}$, with a deposition time of $30 \mathrm{~s}$. Between -0.700 and $-0.600 \mathrm{~V}$ adequate signals were obtained for the three species: $\mathrm{Tl}(\mathrm{I})(\mathrm{i}=3.24 \mathrm{nA})$, $\mathrm{Pb}$ (II)+EDTA and $\mathrm{Cu}$ (II)+EDTA(Fig. 5a). However, upon increasing slightly the potential to $-0.550 \mathrm{~V}$, the signals arising from $\mathrm{Pb}$ (II)-EDTA and $\mathrm{Cu}$ (II)-EDTA were decreased, especially the first one, relative to the Tl(I) signal (Fig. 5b). Increasing further the signal to $-0.500 \mathrm{~V}$ decreased the peak current of $\mathrm{Tl}(\mathrm{I})$ to 2.60 nA (Fig. 5c). Therefore, the optimal potential was considered to be $-0.550 \mathrm{~V}$.

\section{Performance of the optimized method}

Once the optimized parameters were chosen, we investigated the maximum concentrations of $\mathrm{Pb}$ (II) and $\mathrm{Cu}$ (II) that allow quantification of $\mathrm{Tl}(\mathrm{I})$ by DPASV without losing resolution (Fig. 6). For this purpose, the $\mathrm{Tl}(\mathrm{I})$ concentration of $10 \mu \mathrm{g} / \mathrm{L}$ that generates a peak current of $3.24 \mathrm{nA}$ was used as reference. $\mathrm{A} \mathrm{Pb}$ (II) concentration of $2 \mathrm{mg} / \mathrm{L}+$ EDTA did not produce a noticeable signal (Fig. 6a), whereas the same concentration of $\mathrm{Cu}$ (II) did produce a signal of similar amplitude as that of $\mathrm{Tl}(\mathrm{I}) . \mathrm{Pb}(\mathrm{II})$ detection was attained at a concentration closer to $10 \mathrm{mg} / \mathrm{L}$ (Fig. 6b), obviously progressively increasing as its concentration was raised (Fig. 6b-d). For a concentration of 25 $\mathrm{mg} / \mathrm{L} \mathrm{Pb}$ (II) and $5 \mathrm{mg} / \mathrm{L} \mathrm{Cu}(\mathrm{II})$, the $\mathrm{Tl}(\mathrm{I})$ peak current was decreased by $10 \%$ (Fig. 6d), and based upon common practice in routine analysis we decided to consider a $10 \%$ variation as the maximum acceptable decrease in peak amplitude. Therefore, these two metals were defined as interferents of the Tl(I) signal under the optimized DPASV method conditions at a $\mathrm{Pb}$ (II) concentration 2000 times higher, and a $\mathrm{Cu}$ (II) concentration 400 times higher than that of Tl(I), with the chosen EDTA concentration of $0.1 \mathrm{M}$.

Figure 6e shows the corresponding voltamperogram obtained for the optimized method but keeping the scan rate of the original method at $20 \mathrm{mV} / \mathrm{s}$. It is clear that the Tl(I) signal does not separate optimally from those of $\mathrm{Pb}(\mathrm{II})$ and $\mathrm{Cu}$ (II) (i.e., they do not reach background levels between them), as occurs at a scan rate of $10 \mathrm{mV} / \mathrm{s}$.

In the standard AB074 Metrohm (Metrohm 1993) method (Dhaneswar and Zarparkar 1980, Lukaszewski et al. 2003), these limiting concentrations are 1000 and 100 times higher, respectively. Figure 6f shows the corresponding voltamperogram obtained with this 

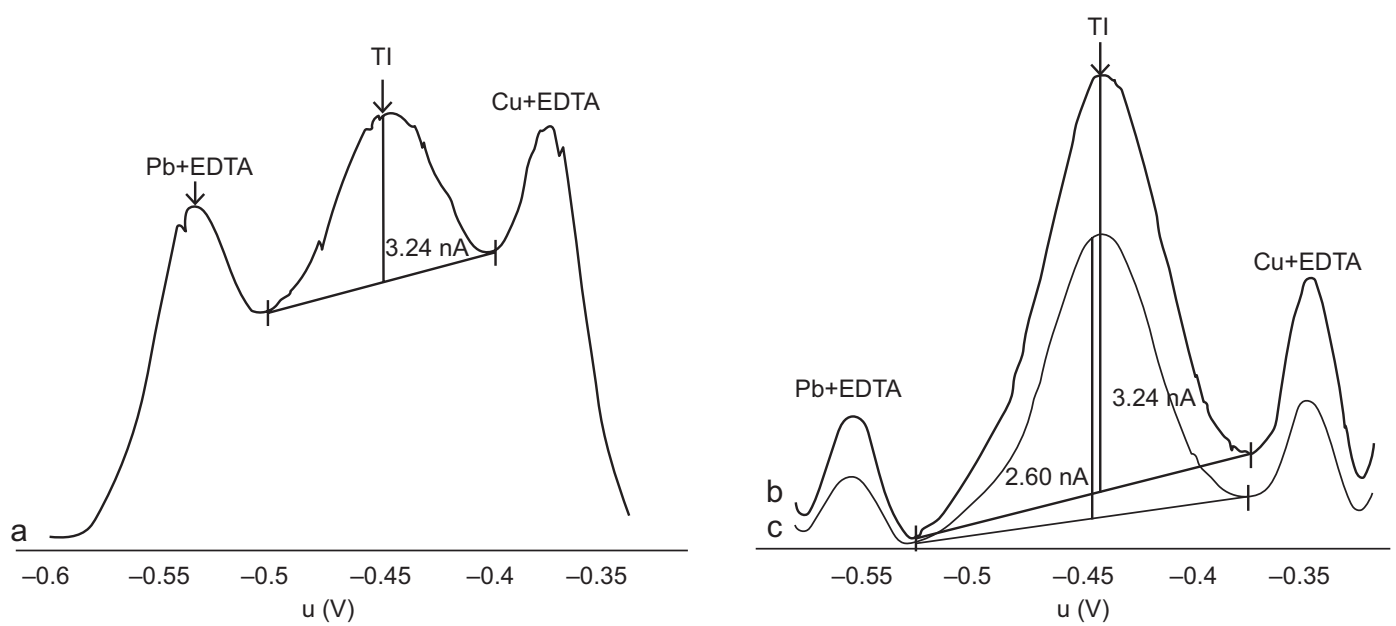

Fig. 5. Effect of deposition potential on the peak current of differential pulse anodic stripping voltammetry (DPASV) potential (U) signals for Tl(I), for $10 \mu \mathrm{g} / \mathrm{L} \mathrm{Tl}(\mathrm{I})+10 \mathrm{mg} / \mathrm{L} \mathrm{Pb}(\mathrm{II})+2 \mathrm{mg} / \mathrm{L} \mathrm{Cu}(\mathrm{II})$ and $0.1 \mathrm{M}$ ethylenediaminetetraacetic acid (EDTA), (a) from -0.700 to $-0.600 \mathrm{~V}$, (b) $-0.550 \mathrm{~V}$ and (c) $-0.500 \mathrm{~V}$. Deposition time $30 \mathrm{~s}$, scan rate $10 \mathrm{mV} / \mathrm{s}$, pulse amplitude $0.050 \mathrm{~V}$. Intensity scales are arbitrary

method, which clearly additionally shows a much lower peak resolution especially between the $\mathrm{Pb}(\mathrm{II})$ and the $\mathrm{Tl}(\mathrm{I})$ signals, as compared to the optimized parameters (Fig. 6c, $\mathbf{d})$, and vary among graphs.

\section{PERFORMANCE OF THE OPTIMIZED METHOD IN THE PRESENCE OF Pb(II) AND Cu(II)}

\section{Detection limit, quantification limit and sensitivity}

The standard curve for $\mathrm{Tl}(\mathrm{I})$ is shown in figure 7a for the concentration range of 2.3 to $20 \mu \mathrm{g} / \mathrm{L}$ with the optimized method. The corresponding linear equation obtained was: peak current $(\mathrm{nA})=0.2334$ $\times(\mathrm{Tl}[\mathrm{I}])(\mu \mathrm{g} / \mathrm{L})+0.9016$, and the correlation coefficient $r^{2}$ was 0.999 . The detection and quantification limits (DL and QL) were 2 and $7 \mu \mathrm{g} / \mathrm{L}$, respectively, and were determined as the $\mathrm{Tl}(\mathrm{I})$ concentration that provides a signal equal to three and 10 times the standard deviation (noise) of the blank $(0.157 \mathrm{nA})$, respectively through the criterion of IUPAC (1995) from the mathematical relation: $\mathrm{DL}=3 * \mathrm{~S} / \mathrm{m}$ and $\mathrm{QL}$ $=10 * \mathrm{~S} / \mathrm{m}$ where $\mathrm{S}$ is the standard deviation for 10 blank and is the sensitivity that corresponds to the constant of proportionality between the signal and the concentration.

The Tl(I) standard curve for the conditions of the original method (AB074 from Metrohm [Dhaneswar and Zarparkar 1980, Lukaszewski et al. 2003]) is shown in figure $\mathbf{7 b}$ for 1000 times higher $\mathrm{Pb}$ (II) and
100 times higher $\mathrm{Cu}(\mathrm{II})$. It is clearly a more sensitive curve with a higher slope (0.602), which decreases the $\mathrm{Tl}(\mathrm{I}) \mathrm{DL}$ and QL ca. 10 times.

However, the sacrifice in detection limit shown by the optimized method allows an increase in $\mathrm{Pb}$ (II)/ $\mathrm{Tl}(\mathrm{I})$ and $\mathrm{Cu}(\mathrm{II}) / \mathrm{Tl}(\mathrm{I})$ of twice and four times the latter, respectively. The decrease in sensitivity of the optimized method is basically due to a decrease in the scanning speed to half the value of the standard method. This decrease is necessary to allow a better separation among the three signals (Fig. 6a-c), and therefore to increase the concentration limits of both interferents. If a lower detection of $\mathrm{Tl}(\mathrm{I})$ was desired, the scanning rate could be increased to the original value of $20 \mathrm{mV} / \mathrm{s}$, but the analyst should be aware that the signal separation would be sacrificed in this case (Fig. 6e).

\section{Accuracy and precision}

The accuracy of the method is verified by the analysis of a certified reference material, or by comparing the results with those obtained by another reliable method on the same sample. If none of these procedures is possible, the recovery tests are used to provide evidence on the validity of the results. In this work the method of addition/recovery was used to assess the accuracy calculating the percentage of recovery $(\% \mathrm{R})$ using equation 4 :

$\% \mathrm{R}=\frac{\mathrm{C}_{\mathrm{F}}-\mathrm{C}_{\mathrm{U}}}{\mathrm{C}_{\mathrm{A}}} * 100$ 

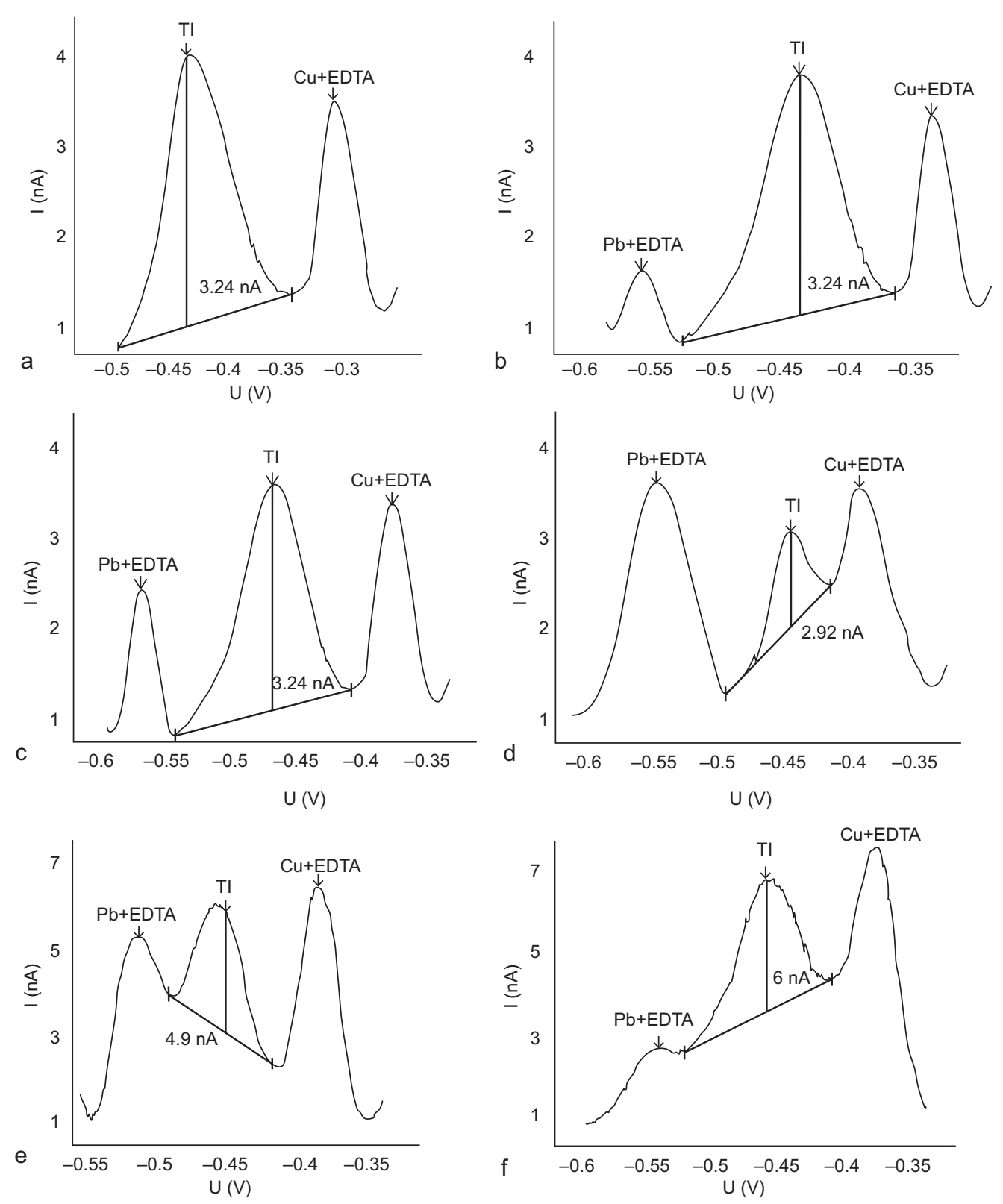

Fig. 6. Influence of the $\mathrm{Pb}(\mathrm{II})$ and $\mathrm{Cu}(\mathrm{II})$ concentrations on the $10 \mu \mathrm{g} / \mathrm{L} \mathrm{Tl}(\mathrm{I})$ differential pulse anodic stripping voltammetry (DPASV) potential (U) signal in the presence of $0.1 \mathrm{M}$ ethylenediaminetetraacetic acid (EDTA), with a deposition time of $30 \mathrm{~s}$, deposition potential of $-0.550 \mathrm{~V}$, scan rate of $10 \mathrm{mV} / \mathrm{s}$ and a pulse amplitude of $0.050 \mathrm{~V}$. (a) $2 \mathrm{mg} / \mathrm{L} \mathrm{Pb}$ (II) $+2 \mathrm{mg} / \mathrm{L} \mathrm{Cu}$ (II), (b) $10 \mathrm{mg} / \mathrm{L} \mathrm{Pb}$ (II) + $3 \mathrm{mg} / \mathrm{L} \mathrm{Cu}$ (II), (c) $20 \mathrm{mg} / \mathrm{L} \mathrm{Pb}$ (II) $+4 \mathrm{mg} / \mathrm{L} \mathrm{Cu}$ (II), (d) $25 \mathrm{mg} / \mathrm{L} \mathrm{Pb}$ (II) $+5 \mathrm{mg} / \mathrm{L} \mathrm{Cu}$ (II), (e) $20 \mathrm{mg} / \mathrm{L}$ $\mathrm{Pb}$ (II) $+4 \mathrm{mg} / \mathrm{L} \mathrm{Cu}$ (II) scan rate of $20 \mathrm{mV} / \mathrm{s}$, and (f) $10 \mathrm{mg} / \mathrm{L} \mathrm{Pb}$ (II) $+1 \mathrm{mg} / \mathrm{L} \mathrm{Cu}$ (II). Deposition time $60 \mathrm{~s}$, deposition potential of $-0.700 \mathrm{~V}$, scan rate of $20 \mathrm{mV} / \mathrm{s}$ and a pulse amplitude of $0.050 \mathrm{~V}$

Where $\mathrm{C}_{\mathrm{F}}$ is the concentration of analyte measured in the fortified sample, $\mathrm{C}_{\mathrm{U}}$ is the concentration of analyte measured in the sample without fortification, and $\mathrm{C}_{\mathrm{A}}$ is the concentration of the analyte added.

Precision is the level of agreement between the results obtained when we apply the same analytical method several times to the same sample. The lower the degree of agreement, the lower the precision, and this is indicative of the method's random errors, which cause the result to deviate from the mean value. In contrast, the greater the degree of agreement between the results, the greater the precision 


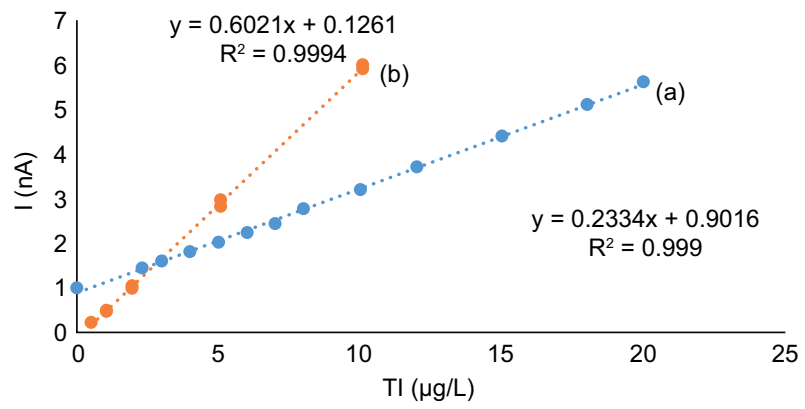

Fig. 7. Standard Tl(I) curve determined by differential pulse anodic stripping voltammetry (DAPSV) in the presence of $0.1 \mathrm{M}$ ethylenediaminetetraacetic acid (EDTA): (a) in the optimized conditions of 2000 times higher $\mathrm{Pb}$ (II) concentrations, and 400 times higher $\mathrm{Cu}$ (II) concentrations (deposition potential of $-0.550 \mathrm{~V}$, deposition time $30 \mathrm{~s}$, scan rate $10 \mathrm{mV} / \mathrm{s}$, pulse amplitude $0.050 \mathrm{~V} 9$; and (b) in the conditions of the original AB074 method (Metrohm 1993) (adapted from Dhaneswar and Zarparkar 1980) for 1000 times higher $\mathrm{Pb}$ (II) concentrations and 100 times higher $\mathrm{Cu}(\mathrm{II})$ concentrations (deposition potential $-0.700 \mathrm{~V}$, deposition time $60 \mathrm{~s}$, scan rate $20 \mathrm{mV} / \mathrm{s}$, pulse amplitude $0.050 \mathrm{~V}$ )

of the analytical method, indicating that the method does not present random errors or that these errors are acceptable.

The precision is calculated either as the absolute standard deviation (S), or as the coefficient of variation $(\mathrm{CV})$, which is the percentage of $\mathrm{S}$ with respect to the average $(\dot{X})$.

Table I shows the results of the analysis of the accuracy and precision of the method under study. The mean recovery achieved $(100.8 \%)$ indicates that the proposed method shows the accuracy required to be considered appropriate for thallium determinations (the additional calculated $0.8 \%$ is due to experimental error). On the other hand, the repeatability of the $\mathrm{Tl}$ concentration values in the analyses, with low values of coefficients of variation, indicate that the method is precise.

\section{REAL SAMPLE ANALYSIS}

To further evaluate the feasibility and practicality of the optimized method nine real samples of soils contaminated by metallurgical waste were selected from the San Luis Potosí Mining District in the state of San Luis Potosí (SLP), Mexico (22 9' 23.292" N; $100^{\circ} 59^{\prime} 7.947^{\prime}$ W) (Santana-Silva 2016, RuizGarcía 2017, Cruz-Hernández et al. 2018), and processed through an extraction procedure (cf. the Materials and Methods section), because concentrations from total digestions surpass the $\mathrm{Pb}(\mathrm{II})$ and $\mathrm{Cu}$ (II) limits reported in the present work for the Tl(I) determination. The mineralogical composition of the samples is highly variable. There are major components of most of the primary mineral samples such as quartz, feldspar and plagioclase and minor secondary iron oxide minerals such as hematite and goethite in samples SLP01, SLP02 and SLP08. In samples SLP03, SLP04 and SLP07 the presence of mica and secondary minerals (neoformed or not) such as gypsum, jarosite and kaolinite as minor components is noteworthy (Cruz-Hernández et al. 2018). These samples exhibit high contents of arsenic, lead, copper, manganese and total iron. The manganese present correlates strongly with the total $\mathrm{Tl}$ content suggesting a strong association between these two metals (Cruz-Hernández et al. 2018).

The experimental results are shown in figure 8 by taking sample SLP06 as an example. This sample was selected because it shows the highest contents of total thallium, lead and copper of all samples investigated, according to analyses performed by Ruiz-García (2017).

Figure 8a shows the inability of the original method for adequately separating the peaks of Tl(I), $\mathrm{Pb}$ (II) + EDTA and $\mathrm{Cu}$ (II) + EDTA. This is mainly because the concentrations of $\mathrm{Pb}$ (II) and $\mathrm{Cu}$ (II) extracted in the sample exceed the limits allowed by the original AB074 Metrohm method (adapted from

TABLE I. RESULTS OF THE ANALYSIS OF ACCURACY AND PRECISION OF THE METHOD BEING STUDIED*

\begin{tabular}{|c|c|c|c|c|c|c|c|c|}
\hline \multirow{2}{*}{ Sample } & \multicolumn{3}{|c|}{ Initial concentration of the sample } & \multicolumn{3}{|c|}{ Concentration of the added pattern } & \multirow{2}{*}{$\begin{array}{l}\text { Percentage of } \\
\text { recovery }(\%)\end{array}$} & \multirow{2}{*}{$\begin{array}{c}\text { Coefficient of } \\
\text { variation }(\mathrm{CV} ; \%)\end{array}$} \\
\hline & $\mathrm{Tl}(\mu \mathrm{g} / \mathrm{L})$ & $\mathrm{Pb}(\mathrm{mg} / \mathrm{L})$ & $\mathrm{Cu}(\mathrm{mg} / \mathrm{L})$ & $\mathrm{Tl}(\mu \mathrm{g} / \mathrm{L})$ & $\mathrm{Pb}(\mathrm{mg} / \mathrm{L})$ & $\mathrm{Cu}(\mathrm{mg} / \mathrm{L})$ & & \\
\hline 1 & 10 & 20 & 4 & 0.5 & 1 & 0.2 & 104 & 0.9 \\
\hline 2 & 10 & 20 & 4 & 2.5 & 5 & 1 & 99 & 2.62 \\
\hline 3 & 10 & 20 & 4 & 9 & 18 & 3.6 & 99.4 & 1.31 \\
\hline
\end{tabular}

Global recovery $(\%)=100.8$; global CV $(\%)=1.69$

*The values expressed are the average of eight independent measurements 

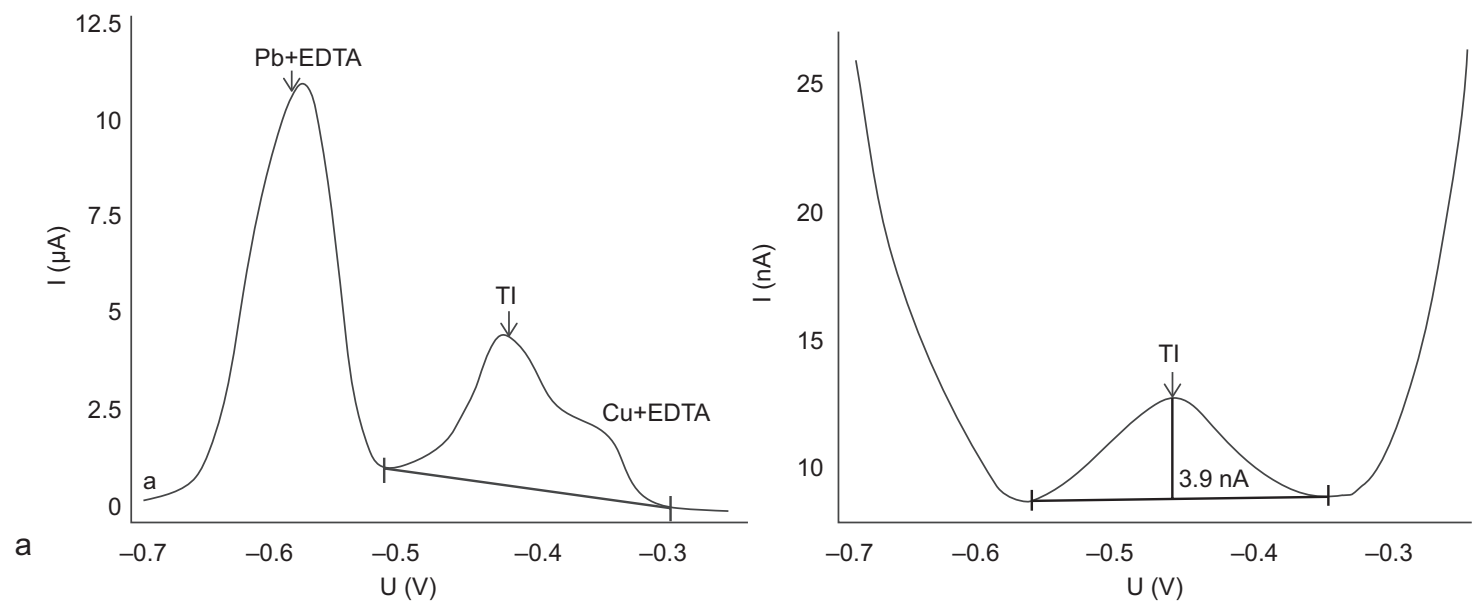

Fig. 8. Voltamperograms obtained for the real sample SLP06 after extracting with acetic acid according to the BCR sequential extraction method, using (a) the original AB074 Metrohm method (adapted from Dhaneswar and Zarparkar 1980); and (b) the optimized method from this work

Dhaneswar and Zarparkar 1980). When applying the optimized method (Fig. 8b) the clear definition of the thallium peak, separated from the $\mathrm{Pb}$ (II) and $\mathrm{Cu}(\mathrm{II})$ peaks, becomes evident. Therefore, quantification of thallium using the optimized method developed here is feasible and highly reliable for samples with these characteristics. Table II shows the thallium concentrations in $\mathrm{mg} / \mathrm{kg}$ obtained in each of the samples by DPASV.

These results suggest the need to study the geochemical behavior and thallium speciation in this

TABLE II. RESULTS FOR THE DETERMINATION OF Tl(I) IN REAL SAMPLES FROM EXTRACTIONS USING ACETIC ACID ACCORDING TO THE EUROPEAN BUREAU OF REFERENCE (BCR) SEQUENTIAL EXTRACTION METHOD

\begin{tabular}{lc}
\hline Samples & $\begin{array}{c}\text { Concentration determined by } \\
\text { DPASV }(\mathrm{mg} / \mathrm{kg}) \\
\text { mean } \pm \text { standard deviation }(\mathrm{n}=3)\end{array}$ \\
\hline SLP01 & $0.065 \pm 0.0006$ \\
SLP02 & $0.28 \pm 0.015$ \\
SLP03 & $0.05 \pm 0.05$ \\
SLP 04 & $0.18 \pm 0.2$ \\
SLP 05 & $0.05 \pm 0.06$ \\
SLP 06 & $1.18 \pm 0.04$ \\
SLP 07 & $0.22 \pm 0.005$ \\
SLP 08 & $0.89 \pm 0.21$ \\
SLP09 & $3.2 \pm 0.07$ \\
\hline
\end{tabular}

DPASV: differential pulse anodic stripping voltammetry
Mexican zone and extend the study to other areas of the country, on account of the extreme toxicity of this elememt. The results also show that the optimized method proposed has potential practical applications for the determination of $\mathrm{Tl}(\mathrm{I})$ in the presence of $\mathrm{Pb}$ and $\mathrm{Cu}$ in real soil samples.

\section{CONCLUSIONS}

Differential pulse anodic stripping voltammetry is a robust technique to quantify $\mathrm{Tl}(\mathrm{I})$ at low concentrations, similar to those commonly encountered in soils and sediments. But it can also be used for samples with high Tl(I) contents, provided the maximum molar ratios of $\mathrm{Pb}$ (II)/Tl(I) of 2000 and $\mathrm{Cu}$ (II)/Tl(I) of 400 found in the present work for the optimized method, are not surpassed. This method improved from the suggested standard method (Dhaneswar and Zarparkar 1980, Metrohm 1993, Lukaszewski et al. 2003), in which the maxima are $\mathrm{Pb}$ (II)/Tl(I) of 1000 and $\mathrm{Cu}(\mathrm{II}) / \mathrm{Tl}(\mathrm{I})$ of 100. The parameters varied as follows: deposition time was decreased from 60 to $30 \mathrm{~s}$, deposition potential was increased from -0.700 to $-0.550 \mathrm{~V}$, scan rate was halved from 20 to $10 \mathrm{mV} / \mathrm{s}$, and the pulse amplitude was kept at $0.050 \mathrm{~V}$. With these adjustments, the $\mathrm{Tl}(\mathrm{I})$ detection and quantification limits were sacrificed from 0.18 and $0.6 \mu \mathrm{g} / \mathrm{L}$, to 2 and $7 \mu \mathrm{g} / \mathrm{L}$, respectively. The study of the validation parameters concludes that the optimized method is validated. 


\section{ACKNOWLEDGMENTS}

Y. Cruz-Hernández is thankful to the Consejo Nacional de Ciencia y Tecnología (CONACyT) for the fellowship received to perform Ph.D. studies and for their support to the Laboratorio Nacional de Geoquímica y Mineralogía (LANGEM). The authors are grateful to the PAPIIT IG100215, and UC-MEXUS-CONACyT CN 15-44 projects for the financial support to perform this investigation. They also acknowledge the students and technicians of the Environmental Geochemistry Laboratory of the Geology Institute at UNAM for their support and collaboration, especially to Mismel Ruiz, Fabiola Vega, Arturo Mendoza and David Alcalde.

\section{REFERENCES}

Batley G.E. and Florence T.M. (1975). Determination of thallium in natural waters by anodic stripping voltammetry. J. Electroanal. Chem. 61 (2), 205-211.

DOI: $10.1016 / \mathrm{S} 0022-0728(75) 80251-8$

Bond A.M. (1980). Modern polarographic methods in analytical chemistry. Dekker, Mishawaka, IN, USA, 341 pp. DOI: 10.1149/1.2129594

Carvalho L., Nascimento P., Koschinsky A., Bau M., Stefanello R., Spengler C., Bohrer D. and Jost C. (2007). Simultaneous determination of cadmium, lead, cooper, and thallium in highly saline samples by anodic stripping voltammetry (ASV) using mercury-film and bismuth-film electrodes. Electroanalysis 19 (16), 17191726. DOI: 10.1002/elan.200703922

Ciszewski A., Wasiak W. and Ciszewska W. (1997). Differential pulse anodic stripping voltammetric determination of thallium in human hair samples of persons in permanent contact with lead in their workplace. Anal. Chim. Acta 335 (3), 225-229.

DOI: 10.1016/S0003-2670(96)00323-6

Cruz-Hernández Y., Ruiz-García M., Villalobos M., Martin Romero F., Meza-Figueroa D., Garrido F., HernándezAlvarez E. and Pi-Puig T. (2018). Fractionation and mobility of thallium in areas impacted by miningmetallurgical activities. Identification of water-soluble Tl(I) fraction. Environ. Pollut. 237, 154-165.

DOI: 10.1016/j.envpol.2018.02.031

Cvjetko P., Cvjetko I. and Pavlica M. (2010). Thallium toxicity in humans. Arh. Hig. Rada. Toksikol. 61 (1), 111-119. DOI: 10.2478/10004-1254-61-2010-1976

Chulsung K. (1996). Extraction of lead using EDTA: Factors affecting extraction, effects of amorphous iron and recycling of used EDTA. Doctoral Dissertation. Iowa State University, Ames City, USA, 167 pp.
Dhaneswar R.G. and Zarparkar L.R. (1980). Simultaneous determination of thallium and lead at trace levels by anodic-stripping voltammetry. Analyst 108 (1249), 386-390. DOI: 10.1039/AN9800500386

Dong W. and Zhang L. (2017). Constructed ILs coated porous magnetic nickel cobaltate hexagonal nanoplates sensing materials for the simultaneous detection of cumulative toxic metals. J. Hazard. Mater. 333, 23-31. DOI: $10.1016 /$ j.jhazmat.2017.03.034

Espinosa-Castellón E.R and Alvarado-Gámez A.L. (2012). Desarrollo y validación de un método voltamperométrico para determinar estaño en agua. Rev. Int. Contam. Ambie. 28 (1), 61-72.

Galván-Arzate S. and Santamaría A. (1998). Thallium toxicity. Toxicol. Lett. 99 (1), 1-13.

DOI: 10.1016/S0378-4274(98)00126-X

Harris P., Scullion T., Sebesta S. and Claras G. (2003). Measuring sulfate in subgrade soil: Difficulties and triumphs. Transp. Res. Rec. 1837 (1), 3-11.

DOI: $10.3141 / 1837-01$

Gómez-González M.A., García-Guinea J., Laborda F. and Garrido F. (2015). Thallium occurrence and partitioning in soils and sediments affected by mining activities in Madrid province (Spain). Sci. Total Environ. 536, 268-278. DOI: 10.1016/j.scitotenv.2015.07.033

Inam R., Somer G. and Kucukoglu B. (1999). Determination of cadmium, lead and selenium in Medicago sativa herb by differential pulse anodic stripping voltammetry. Anal. Sci. 15, 493-496. DOI: 10.2116/analsci.15.493

IUPAC (1995). Recommendations. Pure Appl. Chem. 67 (10), 1699-1723.

DOI: $10.1351 /$ pac199567101699

Keith L.H. and Telliard W.A. (1979). Priority pollutants: I-a perspective view. Environ. Sci. Technol. 13 (4), 416-423. DOI: 10.1021/es60152a601

Korolczuk M. (1999). Voltammetric determination of $\mathrm{Cr}(\mathrm{VI})$ in natural water in the presence of bipyridine following its deposition to the metallic state. Electroanalysis 11 (16), 1218- 1221.

DOI: 10.1002/(SICI)1521-4109(199911)11:16< 1218::AID-ELAN1218>3.0.CO;2-Q

Krasnodębska-Ostręga B. and Stryjewska E. (2004). Voltammetric determination of thallium in water and plant material. Anal. Chem. 49 (4), 519-526.

Laborda E., González J. and Molina A. (2014). Recent advances on the theory of pulse techniques: A mini review. Electrochem. Commun. 43, 25-30. DOI: 10.1016/j.elecom.2014.03.004

Liu J., Wang J., Chen Y., Xie X., Qi J., Lippold H., Luo D., Wang Ch., Su L., He L. and Wu Q. (2016). Thallium transformation and partitioning during $\mathrm{Pb}-\mathrm{Zn}$ smelting and environmental implications. Environ. Pollut. 212, 77-89. DOI: 10.1016/j.envpol.2016.01.046 
Lukaszewski Z., Pawlak K. and Ciszewski A. (1980). Determination of thallium and lead in cadmium salts by anodic stripping voltammetry with addition of surfactants to suppress the cadmium peaks. Talanta 27 (2), 181-185. DOI: 10.1016/0039-9140(80)80035-X

Lukaszewski Z., Karbowska B. and Zembrzuski W. (1992). Determination of thallium in soils by flow-injectiondifferential pulse anodic stripping voltammetry. Talanta 39 (3), 221-227. DOI: 10.1016/0039-9140(92)80024-8

Lukaszewski Z. and Piela A. (1996). Direct determination of ultratraces of thallium in water by flow-injectiondifferential-pulse anodic stripping voltammetry. Anal. Chim. Acta 318 (2), 159-165. DOI: $10.1016 / 0003-2670(95) 00436-X$

Lukaszewski Z., Karbowska B. and Zembrzuski W. (2003). Determination of mobile thallium in soil by flow-injection-differential pulse anodic stripping voltammetry. Electroanalysis 15 (5-6), 480-483.

DOI: $10.1002 /$ elan.200390057

Mahesar S.A., Sherazi S.T., Niaz A., Bhanger M.I., Uddin S. and Rauf A. (2010). Simultaneous assessment of zinc, cadmium, lead and copper in poultry feeds by differential pulse anodic stripping voltammetry. Food Chem. Toxicol. 48 (8-9), 2357-60.

DOI: $10.1016 /$ j.fct.2010.05.071

Metrohm (1993). Application bulletin AB074. Voltammetric analysis methods for thallium, antimony, bismuth, iron, copper and vanadium. Manual. Metrohm International Headquarters, Editorial Department Metrohm Information, Herisau, Switzerland, 18 pp.

Ngila C., Silavwe N., Jackson K. and Kiptoo E.R. (2005). Voltammetric investigation of the distribution of the hydroxo-, chloro-, EDTA and carbohydrate complexes of lead, chromium, zinc, cadmium and cooper: Potential application to metal speciation studies in brewery wastewaters. Bull. Chem. Soc. Ethiop. 19 (1), 125-138.

Peter A. and Viraraghavan T. (2005). Thallium: A review of public health and environmental concerns and environmental concerns. Environ. Int. 31 (4), 493-501. DOI: 10.1016/j.envint.2004.09.003

Ritchie R. (2004). Chemistry. 2nd ed. Letts and Lonsdale, London, UK, $71 \mathrm{pp}$.

Ruiz-García M. (2017). Movilidad de talio (Tl) en fase acuosa en muestras de jales mineros, residuos metalúrgicos, y suelos contaminados, e inferencias sobre sus asociaciones mineralógicas. Master Dissertation. Instituto de Geología, Universidad Nacional Autónoma de México, Mexico City, Mexico, 91 pp.

Santana-Silva A. (2016). Diseño y evaluación de un método de extracción simple para determinar la bioaccesibilidad de $\mathrm{As}, \mathrm{Pb}, \mathrm{Cu}, \mathrm{Zn}$ y $\mathrm{Cd}$ potencialmente tóxicos en suelos contaminados por residuos minero-metalúrgicos. Master Dissertation. Instituto de
Geología, Universidad Nacional Autónoma de México, Mexico City, Mexico, 98 pp.

Schecher W.D. and McAvoy D.C. (1992). MINEQL+: A software environment for chemical equilibrium modelling. Comput. Environ. Urban Syst. 16 (1), 65-76. DOI: 10.1016/0198-9715(92)90053-T

Surmann P. and Channaa H. (2015). Anodic stripping voltammetry with galinstan as working electrode. Electroanalysis 27 (7), 1726-1732. DOI: 10.1002/elan.201400752

Taylor J.K. (1987). Quality assurance of chemical measurements. 2nd ed. Lewis, Boca Raton, USA, 79-82 pp.

Tremel A., Masson P., Sterckeman T., Baize D. and Mench M. (1997). Thallium in French agrosystems. Thallium contents in arable soil. Environ. Pollut. 95 (3), 293-302. DOI: 10.1016/S0269-7491(96)00145-5

Vaněk A., Grygar T., Chrastný V., Tejnecký V., Drahota P. and Komárek M. (2010a). Assessment of the BCR sequential extraction procedure for thallium fractionation using synthetic mineral mixtures. J. Hazard. Mater. 176 (1-3), 913-918. DOI: 10.1016/j.jhazmat.2009.11.123

Vaněk A., Komárek M., Chrastný V., Bečka D., Mihaljevič M., Šebek O., Panušková G. and Schusterová Z. (2010b). Thallium uptake by white mustard (Sinapis $a l b a \mathrm{~L}$.) grown on moderately contaminated soils. Agro environmental implications. J. Hazard. Mater. 182 (1-3), 303-308. DOI: 10.1016/j.jhazmat.2010.06.030

Von Laar C., Reinke R. and Simon J. (1994). Determination of thallium in soils by differential pulse anodic stripping voltammetry by means of a mercury film electrode. J. Anal. Chem. 349 (8-9), 692-693.

DOI: $10.1007 / \mathrm{BF} 00323483$

Wang R. and Chakrabarti C.L. (2008). Copper speciation by competing ligand exchange method using differential pulse anodic stripping voltammetry with EDTA as competing ligand. Anal. Chim. Acta 614 (2), 153-160. DOI: 10.1016/j.aca.2008.03.007

Wang Y., Zhang X., Zhonghua LV. and Zhu Y. (2013). Determination of thallium in zinc sulfate solution by differential pulse voltammetry. Chin. J. Anal. Chem. 2013 (1).

Wanninen E.V. and Ingman F. (1987). Metal buffers in chemical analysis: Part I. Theoretical considerations. Pure Appl. Chem. 59 (12), 1681 -1692.

DOI: $10.1351 /$ pac198759121681

Wegial K., Jedlinska K. and Bas B. (2016). Application of bismuth bulk annular band electrode for determination of ultratrace concentrations of thallium (I) using stripping voltammetry. J. Hazard. Mater. 310, 199-206. DOI: 10.1016/j.jhazmat.2016.02.036

Wenqi Q., Yalei, C. and Jieshan C. (1992). Indium and thallium background contents in soils in China. Int. J. Environ. Stud. 40 (4), 311-315. DOI: $10.1080 / 00207239208710737$ 